\title{
Article \\ $\beta$-Cyclodextrin-Calcium Complex Intercalated Hydrotalcites as Efficient Catalyst for Transesterification of Glycerol
}

\author{
Guanhao Liu, Jingyi Yang * and Xinru Xu *
}

Citation: Liu, G.; Yang, J.; Xu, X. $\beta$-Cyclodextrin-Calcium Complex Intercalated Hydrotalcites as Efficient Catalyst for Transesterification of Glycerol. Catalysts 2021, 11, 1307. https://doi.org/10.3390/catal11111307

Academic Editor: Maria A. Goula

Received: 27 September 2021

Accepted: 25 October 2021

Published: 29 October 2021

Publisher's Note: MDPI stays neutral with regard to jurisdictional claims in published maps and institutional affiliations.

Copyright: (c) 2021 by the authors. Licensee MDPI, Basel, Switzerland. This article is an open access article distributed under the terms and conditions of the Creative Commons Attribution (CC BY) license (https:/ / creativecommons.org/licenses/by/ $4.0 /)$.
International Joint Research Center of Green Energy Chemical Engineering, East China University of Science and Technology, Meilong Road 130, Shanghai 200237, China; 10110567@mail.ecust.edu.cn

* Correspondence: jyyang@ecust.edu.cn (J.Y.); xrxu86@ecust.edu.cn (X.X.); Tel./Fax: +86-021-6425-2160 (J.Y. \& X.X.)

\begin{abstract}
MgAl-hydrotalcites ( $\beta$-CD-Ca/LDH) was synthesized to convert glycerol into high value-added glycerol carbonate(GC) by transesterification of dimethyl carbonate (DMC) and glycerol in this paper. $\beta$-cyclodextrin-metal complexes and $\beta$-CD$\mathrm{Ca} / \mathrm{LDH}$ was characterized by XRD, FT-IR, SEM, XPS and nitrogen adsorption-desorption. The enrichment of organic reactants in the hydrophobic cavity of $\beta$-cyclodextrin improved the collision probability of reactants. The intercalation of $\beta$-cyclodextrin-calcium complex ( $\beta$-CD-Ca) increased the pore size and basic strength of catalyst. The experiment results showed that the glycerol conversion was $93.7 \%$ and the GC yield was $91.8 \%$ catalyzed by $\beta$-CD-Ca/LDH when the molar ratio of DMC and glycerol was 3:1, the catalyst dosage was $4 \mathrm{wt} . \%$, the reaction temperature was $75{ }^{\circ} \mathrm{C}$ and the reaction time was $100 \mathrm{~min}$ while the glycerol conversion was $49.4 \%$ and the GC yield was $48.6 \%$ catalyzed by $\mathrm{MgAl}-\mathrm{LDH}$ under the same conditions.
\end{abstract}

Keywords: $\beta$-CD-Ca; hydrotalcites; intercalation; transesterification

\section{Introduction}

Cyclodextrin (CD) usually contains several D-glucopyranose units connected by $\alpha$-glycosidic bonds as the degradation product of amylose [1,2]. The outer side of truncated conical cyclodextrin is hydrophilic due to the ports with rich hydroxyl while the inner cavity is hydrophobic owing to the shielding effect of carbon chains [3]. This special structure enables different organic compounds embedded in the inner cavity of cyclodextrin to exist in hydrophilic solvents, which is necessary for the formation of inclusion complexes and molecular assembly systems [4-6].

A-Cyclodextrin, $\beta$-Cyclodextrins and $\gamma$-Cyclodextrin containing 6, 7 and 8 glucopyranosyl units respectively were three kinds of common cyclodextrins [7]. $\beta$-CD was widely used and studied because of its moderate cavity size, excellent physicochemical properties and relatively low price [8,9]. Cyclodextrin derivatives and their composite with different materials greatly expanded the application of cyclodextrin in different fields [10].

Chen et al. [11] synthesized water-soluble complexes by nestification of $\beta$-cyclodextrin and a variety of hydrophobic monomers. The even dispersion of hydrophobic monomers in aqueous solution realized the aqueous dispersion polymerization by induced selfassembly of monomers. Prochowicz et al. [12] considered that the coordination flexibility of $\beta$-cyclodextrin and metal ions enabled the properties of $\beta$-cyclodextrin derivatives controllable in aqueous environment. Trans et al. [13] used $\beta$-Cyclodextrin derivatives as ligands of rhodium ions to catalyze the aqueous hydroformylation of water-soluble olefins. The structure of $\beta$-cyclodextrin derivatives played an important role on the reaction regioselectivity.

Hydrotalcites has developed rapidly in recent years as columnar compounds composed of positively charged brucite layers and negatively charged anions filled between layers [14-17]. Takagaki et al. [18] considered hydrotalcites as an efficient solid base catalyst for glycerol carbonate formation from glycerol with dialkyl carbonates under mild reaction 
conditions. Szabados et al. [19] synthesized different hydrotalcites using different metal ions and verified their catalytic activity in the transesterification of glycerol and dimethyl carbonate. Zheng et al. [20] and Granados-Reyes et al. [21] used Mg-Al hydrotalcites and $\mathrm{Ca}-\mathrm{Al}$ hydrotalcites as catalyst for the transesterification of glycerol and dimethyl carbonate. The selectivity towards GC was $97.1 \%$ catalyzed by Mg-Al hydrotalcites while the selectivity catalyzed by $\mathrm{Ca}-\mathrm{Al}$ hydrotalcites depended on the content of calcium in the catalyst.

Different kinds of ion groups such as organic groups, inorganic groups, isopoly anions and heteropoly anions can be introduced into hydrotalcites to change the layer spacing or enhance the active centers in hydrotalcites to obtain various functional composites through the design and modification of interlayer exchangeable anions of hydrotalcites [22-27].

Wang et al. [28] introduced sulfonated $\beta$-cyclodextrin into the interlayer of $\mathrm{Mg}$ - $\mathrm{Al}$ hydrotalcites by ion exchange. XRD analysis proved that $\beta$-cyclodextrin were arranged with single layer in hydrotalcite layers and the intercalation of $\beta$-cyclodextrin increased the interlayer spacing of hydrotalcites. Mohanambe et al. [29] synthesized hydrophobic nano inclusion complexes by introducing $\beta$-Cyclodextrin into the interlayer of hydrotalcites. Anthracene molecules of polar solvent can be effectively immobilized in the nano inclusion complexes.

$\beta$-cyclodextrin metal complexes ( $\beta$-CD-M) with alkaline centers were prepared and intercalated into MgAl-LDH in this thesis as heterogeneous catalyst for GC synthesis by transesterification between glycerol and dimethyl carbonate. The structural changes of hydrotalcites before and after intercalation with $\beta$-CD-Ca were analyzed by FT-IR, $\mathrm{XRD}, \mathrm{SEM}$ and nitrogen adsorption-desorption. The optimal reaction conditions were determined by single variable method. The catalytic performance and reuse ability of $\beta-\mathrm{CD}-\mathrm{Ca} / \mathrm{LDH}$ in transesterification was investigated.

\section{Results and Discussion}

\subsection{Characterization of Synthetic $\beta$-Cyclodextrin Derivatives}

$\beta$-cyclodextrin-metal complexes were characterized by FT-IR, XRD, XPS and alkalinity determination respectively as shown in Figures 1 and 2 and Table 1.

Table 1. Basic strength and basic amount of $\beta-C D$ and $\beta$-cyclodextrin-metal complexes.

\begin{tabular}{ccc}
\hline Sample & Basic Strength $\mathbf{( H \_}$ & Basic Amount $(\mathbf{m m o l} / \mathbf{g})$ \\
\hline$\beta-\mathrm{CD}$ & $<9.3$ & 0.23 \\
$\beta-\mathrm{CD}-\mathrm{Zn}$ & $9.3-15.0$ & 0.69 \\
$\beta-\mathrm{CD}-\mathrm{Ni}$ & $15.0-18.4$ & 0.98 \\
$\beta-\mathrm{CD}-\mathrm{Ca}$ & $18.4-26.5$ & 1.89 \\
\hline
\end{tabular}
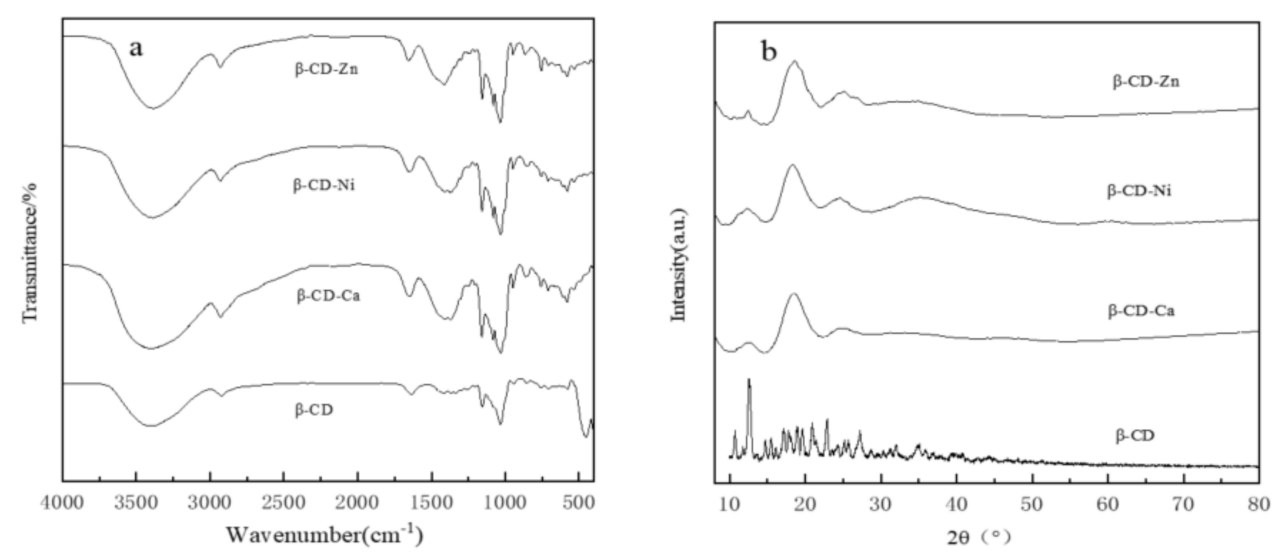

Figure 1. FT-IR spectra (a) and XRD patterns (b) of $\beta$-CD-Zn, $\beta$-CD-Ni, $\beta$-CD-Ca and $\beta$-CD. 

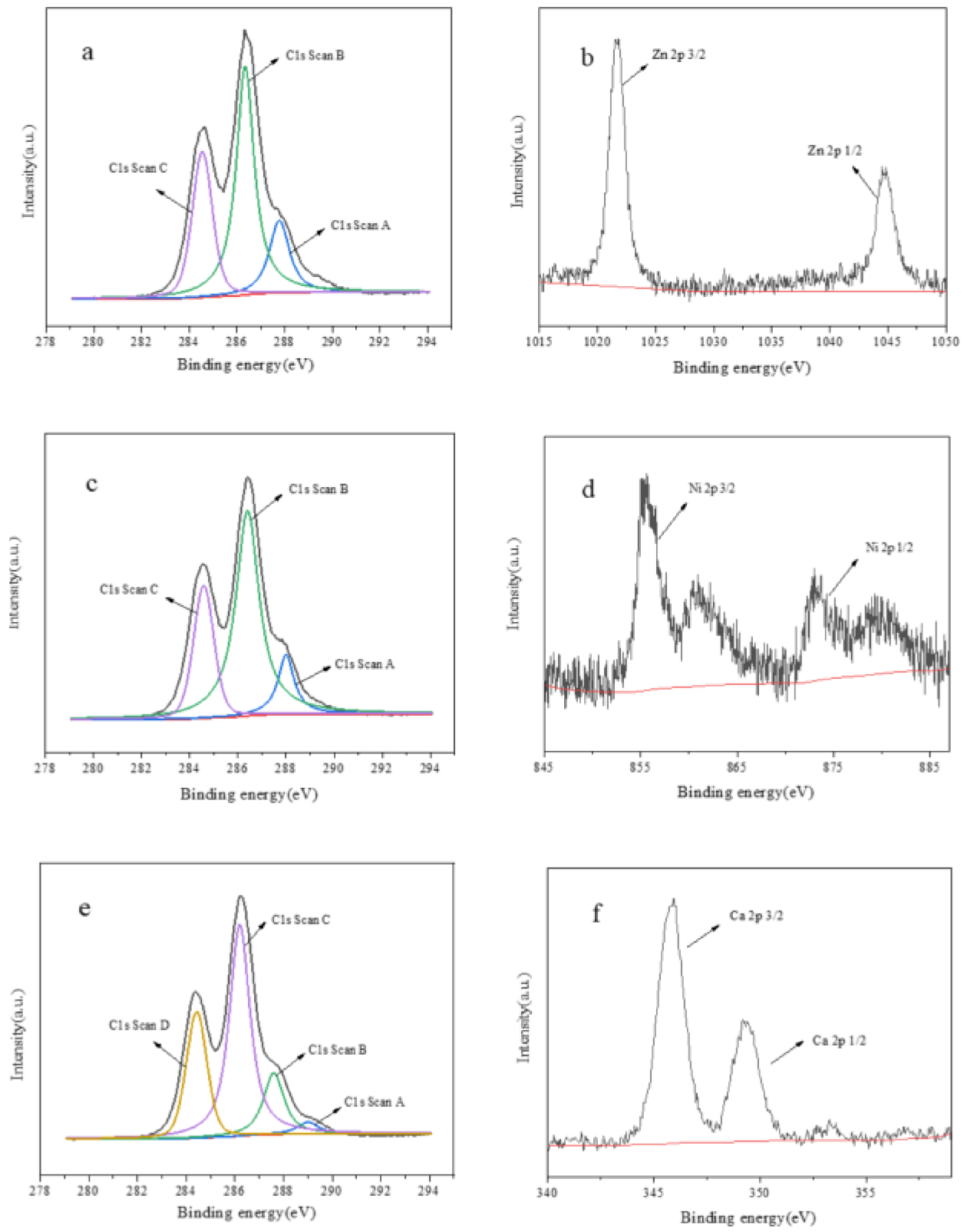

Figure 2. XPS spectra of $\beta-C D-Z n(\mathbf{a}, \mathbf{b}), \beta-C D-N i(\mathbf{c}, \mathbf{d})$ and $\beta-C D-C a(e, f)$.

The FT-IR spectra of $\beta$-CD, $\beta$-CD-Zn, $\beta$-CD-Ni and $\beta$-CD-Ca were shown in Figure 1a. The absorption peak of $\beta-C D$ and $\beta-C D-M$ at $3450 \mathrm{~cm}^{-1}$ was attributed to the stretching vibration of hydroxyl in glucopyranose units. The stretching vibration peak of $\mathrm{C}-\mathrm{O}$ bond in glucopyranose units appeared at $1460 \mathrm{~cm}^{-1}$. The absorption peak at $1590 \mathrm{~cm}^{-1}$ corresponded to the stretching vibration peak of carbon skeleton. The characteristic peak of $\beta-C D-C a$ at $550 \mathrm{~cm}^{-1}$ can be ascribed to the stretching vibration of metal-OH(M-OH) bond, which was absent in the FT-IR spectrum of $\beta-C D$. Everything above indicated that $\beta-\mathrm{CD}-\mathrm{Zn}, \beta-\mathrm{CD}-\mathrm{Ni}$ and $\beta-\mathrm{CD}-\mathrm{Ca}$ with $\mathrm{M}-\mathrm{OH}$ group was synthesized by the reaction of $\beta$-cyclodextrin with zinc nitrate, nickel nitrate and calcium nitrate.

The crystal structures of $\beta-\mathrm{CD}, \beta-\mathrm{CD}-\mathrm{Zn}, \beta-\mathrm{CD}-\mathrm{Ni}$ and $\beta-\mathrm{CD}-\mathrm{Ca}$ were analyzed by XRD as shown in Figure $1 b$. The XRD pattern of $\beta-C D$ exhibited sharp characteristic diffraction peaks while almost no obvious diffraction peaks can be observed in the XRD pattern of $\beta-\mathrm{CD}-\mathrm{Zn}, \beta-\mathrm{CD}-\mathrm{Ni}$ and $\beta-\mathrm{CD}-\mathrm{Ca}$, which suggested that the cyclodextrin metal complexes presented poor crystallinity and amorphous state. This was mainly because the introduction of metal ions changed the original crystal phase of $\beta$-cyclodextrin. 
XPS can be used to determine the bonding forms between metal and $\beta$-cyclodextrin in $\beta-C D-Z n, \beta-C D-N i$ and $\beta-C D-C a$. The blinding energies of $C 1$ s and $Z n$ 2p in $\beta-C D-N i$ were displayed in Figure $2 \mathrm{a}, \mathrm{b}$. Three types of $\mathrm{C}$ species, $\mathrm{C}=\mathrm{O}, \mathrm{C}-\mathrm{O}, \mathrm{C}-\mathrm{C}$ were observed where binding energies were $284.4 \mathrm{eV}, 286.5 \mathrm{eV}$ and $288.1 \mathrm{eV}$. The binding energies of $\mathrm{Zn}$ $2 \mathrm{p}$ were $1022 \mathrm{eV}$ and $1045 \mathrm{eV}$, indicating the existence of $\mathrm{Zn}-\mathrm{O}$ bond. It can be inferred that $\mathrm{C}-\mathrm{O}-\mathrm{Zn}-\mathrm{OH}$ had been formed according to the groups contained in $\beta$-cyclodextrin and the synthesis method of complexes. The $C 1$ s spectrum of $\beta-C D-N i$ was similar to that of $\beta-C D-Z n$ in Figure 2c. The binding energies of $\mathrm{Ni} 2 \mathrm{p}$ were $855.5 \mathrm{eV}$ and $874.0 \mathrm{eV}$ in Figure $2 \mathrm{~d}$, which also suggested the existence of $\mathrm{C}-\mathrm{O}-\mathrm{Ni}-\mathrm{OH}$.

The blinding energies of $C 1$ s and $\mathrm{Ca} 2 \mathrm{p}$ in $\beta$-CD-Ca were displayed in Figure $2 \mathrm{e}, \mathrm{f}$. The $\mathrm{C}$ 1s spectrum revealed the presence of four types of $\mathrm{C}$ species, $\mathrm{C}=\mathrm{O}, \mathrm{C}-\mathrm{O}, \mathrm{C}-\mathrm{C}$ and $\mathrm{O}-\mathrm{C}=\mathrm{O}$ at which the binding energies were $284.4 \mathrm{eV}, 286.5 \mathrm{eV}, 288.1 \mathrm{eV}$ and $289.2 \mathrm{eV}$, respectively. The binding energies of $\mathrm{Ca} 2 \mathrm{p}$ were $346.5 \mathrm{eV}$ and $348.7 \mathrm{eV}$, which proved the formation of $\mathrm{C}-\mathrm{O}-\mathrm{Ca}-\mathrm{OH}$ and $\mathrm{O}=\mathrm{C}-\mathrm{O}-\mathrm{Ca}$ when $\mathrm{Ca}^{2+}$ interacted with $\beta-\mathrm{CD}$ according to the XPS spectra of $\beta$-CD-Ca. The interaction between metal ions and $\beta$-cyclodextrin increased the alkalinity of $\beta$-cyclodextrin-metal complexes at different levels. The data in Table 1 proved that $\beta-C D-C a$ presented stronger alkalinity than $\beta-C D-Z n, \beta-C D-N i$ and $\beta-C D$.

\subsection{Characterization of $\beta-C D$-Ca Intercalated $M g A l$ Hydrotalcites}

The composition and crystal structures of $\beta-\mathrm{CD}-\mathrm{Ca} / \mathrm{LDH}$ were analyzed by XRD, FT-IR, SEM and $\mathrm{N}_{2}$ adsorption-desorption as shown in Figure 3 and Tables 2 and 3.

Table 2. Lattice parameters of MgAl-LDH and $\beta-\mathrm{CD}-\mathrm{Ca} / \mathrm{LDH}$.

\begin{tabular}{|c|c|c|c|c|}
\hline \multirow{2}{*}{ Diffraction Plane } & \multicolumn{2}{|c|}{ MgAl-LDH } & \multicolumn{2}{|c|}{$\beta-\mathrm{CD}-\mathrm{Ca} / \mathrm{LDH}$} \\
\hline & $2 \theta\left({ }^{\circ}\right)$ & $\mathrm{D} / \mathrm{nm}$ & $2 \theta\left(^{\circ}\right)$ & $\mathrm{D} / \mathrm{nm}$ \\
\hline 003 & 11.56 & 0.7655 & 7.14 & 1.238 \\
\hline 006 & 23.46 & 0.3792 & 18.70 & 0.4745 \\
\hline 009 & 30.92 & 0.2892 & 30.36 & 0.2944 \\
\hline 015 & 36.02 & 0.2493 & 35.18 & 0.2551 \\
\hline 018 & 48.34 & 0.1883 & 46.40 & 0.1957 \\
\hline 110 & 61.54 & 0.1507 & 59.42 & 0.1555 \\
\hline 113 & 62.76 & 0.1480 & 60.68 & 0.1526 \\
\hline Layer spacing/nm & \multicolumn{2}{|c|}{0.7655} & \multicolumn{2}{|c|}{1.238} \\
\hline
\end{tabular}

Table 3. Basic strength and basic amount of MgAl-LDH and $\beta-\mathrm{CD}-\mathrm{Ca} / \mathrm{LDH}$.

\begin{tabular}{ccc}
\hline Sample & Basic Strength $\mathbf{( H \_ )}$ & Basic Amount $(\mathbf{m m o l} / \mathbf{g})$ \\
\hline MgAl-LDH & $9.3-15.0$ & 0.47 \\
$\beta-C D-C a / L D H$ & $18.4-26.5$ & 1.68 \\
\hline
\end{tabular}

Figure $3 \mathrm{a}$ was the FT-IR spectra of MgAl-LDH and $\beta-\mathrm{CD}-\mathrm{Ca} / \mathrm{LDH}$. The wide absorption peak at $3440 \mathrm{~cm}^{-1}$ in $\mathrm{MgAl}-\mathrm{LDH}$ was caused by the stretching vibration of hydroxyl in hydrotalcite laminates. The absorption peak at $1470 \mathrm{~cm}^{-1}$ corresponded to C-O bond in the carbonate of hydrotalcites. The peak intensity of hydroxyl at about $3500 \mathrm{~cm}^{-1}$ was enhanced in the spectrum of $\beta-\mathrm{CD}-\mathrm{Ca} / \mathrm{LDH}$ because of rich hydroxyl in $\beta$-cyclodextrin molecules. The absorption peaks at $1454 \mathrm{~cm}^{-1}$ and $1379 \mathrm{~cm}^{-1}$ were ascribed to the stretching vibration of $\mathrm{C}-\mathrm{O}$ and $\mathrm{C}-\mathrm{O}-\mathrm{C}$ in glucopyranose units of $\beta$-cyclodextrin. The characteristic peak of $\beta$-cyclodextrin can be observed in the spectrum of $\beta-\mathrm{CD}-\mathrm{Ca} / \mathrm{LDH}$, which means that $\beta$-CD-Ca had been successfully inserted into the interlayer of $\mathrm{MgAl}$ hydrotalcites.

Figure $3 \mathrm{~b}$ exhibited XRD spectra of $\mathrm{MgAl}$ hydrotalcites before and after intercalation by $\beta-C D-C a$. The characteristic diffraction peaks of hydrotalcites (003), (006), (009), (015), (018), (110) and (113) can be clearly observed when $2 \theta$ is $10.14^{\circ}, 21.70^{\circ}, 33.36^{\circ}, 38.18^{\circ}$, $46.40^{\circ}, 59.42^{\circ}$ and $60.68^{\circ}$. The insertion of $\beta$-cyclodextrin metal complexes did not destroy the crystal structures of hydrotalcites. The narrow and sharp diffraction peaks with high 
intensity indicated that the synthesized $\beta-\mathrm{CD}-\mathrm{Ca} / \mathrm{LDH}$ presented high crystallinity and regular structures.
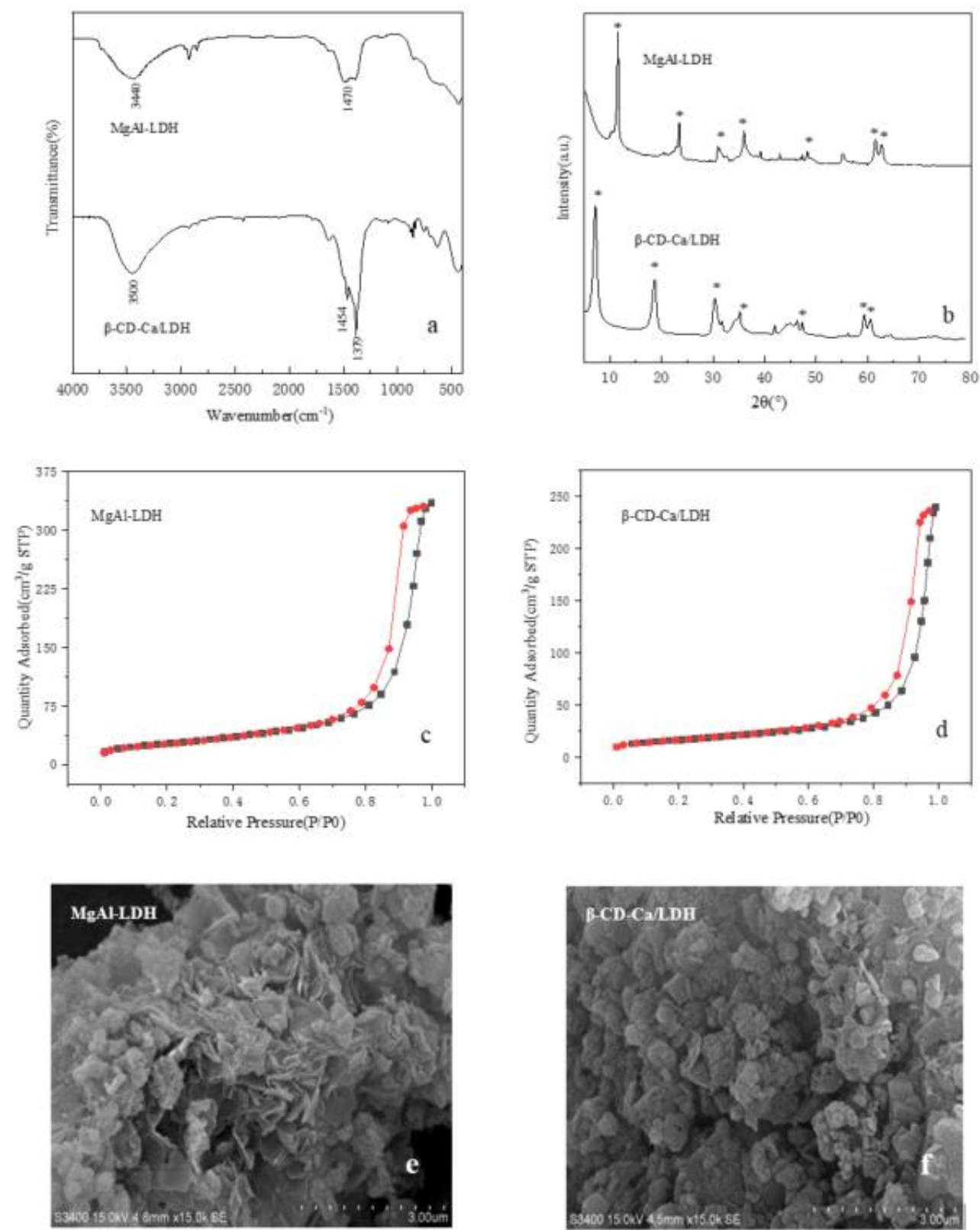

Figure 3. FT-IR spectra (a), XRD patterns (b), adsorption isotherms (c,d) and SEM images (e,f) of $\mathrm{MgAl}-\mathrm{LDH}$ and $\beta-\mathrm{CD}-\mathrm{Ca} / \mathrm{LDH}$ ( ${ }^{*}$ signified characteristic peaks of hydrotalcites).

Table 2 displayed the crystal structure parameters of MgAl-LDH and $\beta-\mathrm{CD}-\mathrm{Ca} / \mathrm{LDH}$. The spacing $\mathrm{D}$ of each characteristic crystal plane can be obtained by Bragg equation. $\mathrm{D}(003)$ was the interlayer spacing of hydrotalcites. The calculation results showed that the interlayer spacing of $\mathrm{MgAl}-\mathrm{LDH}$ and $\beta-\mathrm{CD}-\mathrm{Ca} / \mathrm{LDH}$ was $0.7655 \mathrm{~nm}$ and $1.238 \mathrm{~nm}$, which indicated the intercalation of $\beta-\mathrm{CD}$-Ca increased the interlayer spacing of hydrotalcites effectively. Moreover, the intercalation by $\beta$-CD-Ca in $\mathrm{Mg}$-Al hydrotalcites not only expanded the pore size of catalyst but also enhanced the basic strength of catalyst as shown in Table 3, which was beneficial for the formation of glycerol anions.

Figure $3 c, d$ showed the adsorption isotherms of hydrotalcites before and after intercalation by $\beta$-CD-Ca. Both adsorption isotherms with obvious hysteresis loop belonged to Type IV isotherm in IUPAC classification, indicating MgAl-LDH and $\beta-\mathrm{CD}-\mathrm{Ca} / \mathrm{LDH}$ 
were mesoporous materials. The hysteresis loops with saturated adsorption platform in the adsorption isotherm suggested the regular crystal structures and the uniform pore size distribution of $\mathrm{MgAl}-\mathrm{LDH}$ and $\beta-\mathrm{CD}-\mathrm{Ca} / \mathrm{LDH}$.

The specific surface area and pore size of MgAl-LDH and $\beta-\mathrm{CD}-\mathrm{Ca} / \mathrm{LDH}$ were shown in Table 4. The pore size of hydrotalcites increased from $17.78 \mathrm{~nm}$ to $19.22 \mathrm{~nm}$ due to the intercalation of $\beta-C D-C a$. The layer expansion of hydrotalcites was beneficial for the reduction of diffusion resistance and the collision between reactants and active sites in the catalytic reaction, thus increasing the reaction efficiency. However, some layers of hydrotalcites were squeezed due to the insertion of $\beta-C D-C a$, which resulted in the disappearance of some pore structures and the decrease of specific surface area.

Table 4. Specific surface area and pore size of MgAl-LDH and $\beta$-CD-Ca/LDH.

\begin{tabular}{ccc}
\hline Sample & Specific Surface Area $\left(\mathbf{m}^{2} / \mathbf{g}\right)$ & Pore Size $(\mathbf{n m})$ \\
\hline MgAl-LDH & 117.96 & 15.78 \\
$\beta-C D-C a / L D H$ & 77.20 & 19.22 \\
\hline
\end{tabular}

The morphological characteristics of hydrotalcites before and after intercalation by $\beta$-CD-Ca were observed via SEM. The petal-like lamellar structures of hydrotalcites can be seen in Figure 3e,f. There were visible pore structures on the rough surfaces of MgAl-LDH and $\beta-\mathrm{CD}-\mathrm{Ca} / \mathrm{LDH}$, which was conducive to the diffusion and circulation of reactants in the transesterification system. The lamellae of hydrotalcites was distorted in some way after intercalation by $\beta$-CD-Ca. The intercalation by $\beta$-CD-Ca in $\mathrm{Mg}-\mathrm{Al}$ hydrotalcites not only expanded the pore size of catalyst but also enhanced the basic strength of catalyst as shown in Table 4.

\subsection{Effect of Different $\beta-C D-M$ on Transesterification}

The effect of different $\beta$-cyclodextrin-metal complexes on the transesterification of DMC and glycerol was investigated under the conditions of 3:1 molar ratio of DMC and glycerol, $1 \mathrm{wt} . \%$ catalyst dosage, $75{ }^{\circ} \mathrm{C}$ reaction temperature and $90 \mathrm{~min}$ reaction time.

Figure 4 showed the experimental results of $\beta$-cyclodextrin-metal complexes as catalyst for transesterification. The glycerol conversion catalyzed by $\beta-\mathrm{CD}-\mathrm{Zn}, \beta-\mathrm{CD}-\mathrm{Ni}$ and $\beta$-CD-Ca increased from $45.4 \%, 46.1 \%$ and $46.9 \%$ to $75.8 \%, 85.0 \%$ and $96.6 \%$ respectively when the reaction time increased from $40 \mathrm{~min}$ to $80 \mathrm{~min}$. The GC yield increased from $45.1 \%, 45.5 \%$ and $46.2 \%$ to $74.4 \%, 83.1 \%$ and $93.4 \%$ respectively. The basic groups C-O$\mathrm{Ca}-\mathrm{OH}, \mathrm{C}-\mathrm{O}-\mathrm{Zn}-\mathrm{OH}$ and C-O-Ni-OH were formed by the coordination of $\mathrm{Zn}^{2+}, \mathrm{Ni}^{2+}$ and $\mathrm{Ca}^{2+}$ with port hydroxyl of $\beta$-cyclodextrin. In addition, the enrichment of reactants in the lipophilic cavity of $\beta$-cyclodextrin increased the collision probability of reactants. The glycerol molecules were activated by the interaction with basic hydroxyl when entering the cavity of $\beta$-cyclodextrin. The generated glycerol anions attacked the carbonyl in dimethyl carbonate molecules, thus initiating the transesterification.

The experimental results showed the synthesized $\beta$-cyclodextrin-metal complexes presented different catalytic ability on the transesterification. Nickel ions and zinc ions tended to form the cap-structure due to the existence of $\mathrm{d}$ orbit, thus hindering the entry and exit of substances at the port of $\beta$-cyclodextrin, which led to weaker catalytic effect than $\beta$-CD-Ca. Calcium ions were not easy to form metal bridging complexes compared with transition metal ions nickel and zinc, which was conducive to the contact of reactants. Therefore, $\beta-\mathrm{CD}-\mathrm{Ca}$ was used as a research object in the further experiment. 

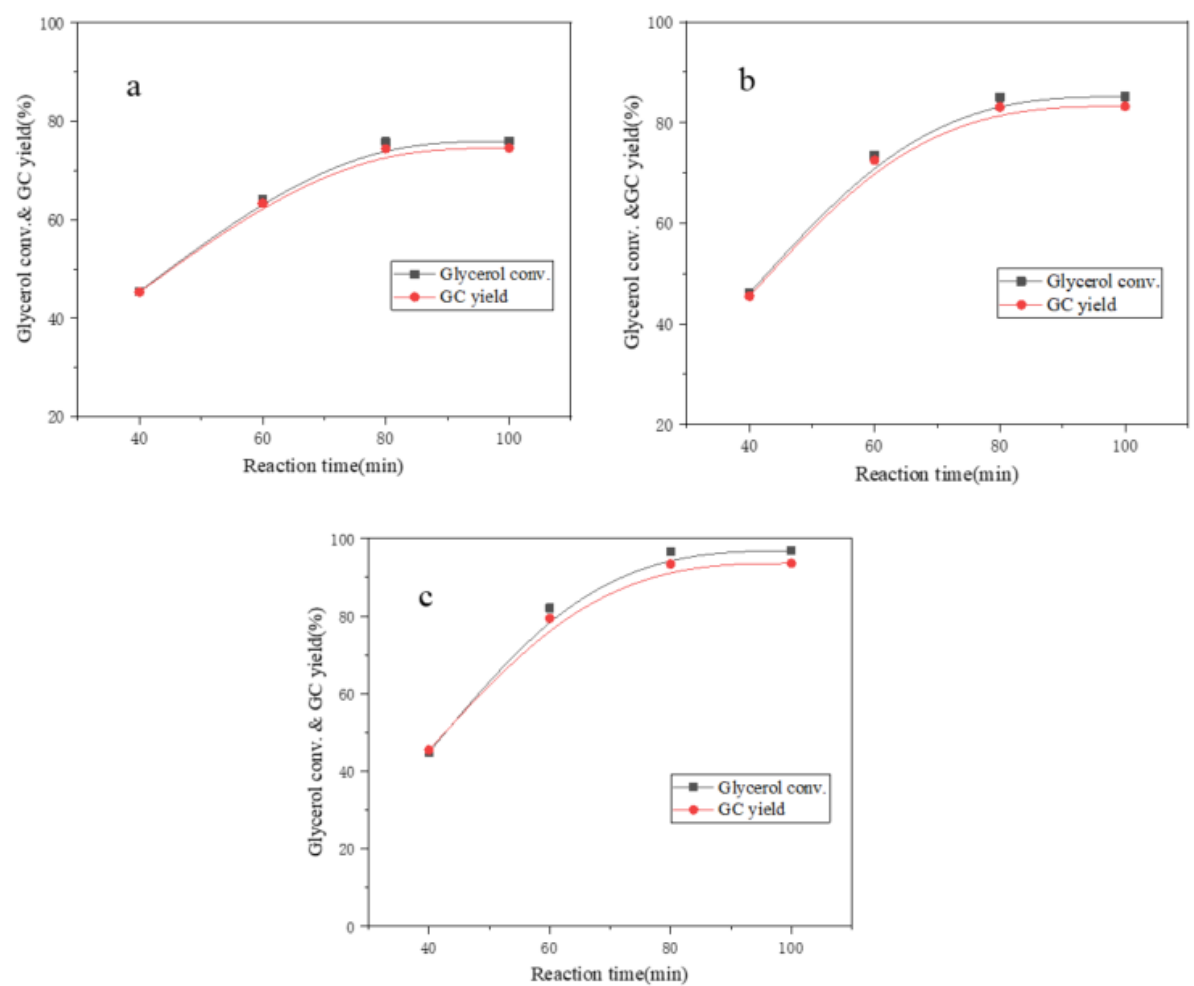

Figure 4. Glycerol conversion and GC yield catalyzed by $\beta-\mathrm{CD}-\mathrm{Zn}(\mathbf{a}), \beta-\mathrm{CD}-\mathrm{Ni}(\mathbf{b})$ and $\beta-\mathrm{CD}-\mathrm{Ca}$ (c).

\subsection{Effect of Molar Ratio of $\beta$-Cyclodextrin and Metal Ions in $\beta-C D$-Ca on Transesterification}

The effect of molar ratio of $\beta$-cyclodextrin and metal ions in $\beta$-CD-Ca on catalytic performance was investigated under the conditions of 3:1 molar ratio of DMC and glycerol, $1 \mathrm{wt} . \%$ catalyst dosage, $75^{\circ} \mathrm{C}$ reaction temperature and $90 \mathrm{~min}$ reaction time.

The glycerol conversion rate was $81.2 \%$, and the GC yield was $80.3 \%$ when the molar ratio of $\beta$-cyclodextrin and calcium ion was 1:1 in Figure 5. The glycerol conversion rate increased to $96.6 \%$ and the GC yield reached $93.4 \%$ when the molar ratio of $\beta$-cyclodextrin and calcium ion was 1:2. However, excessive metal ions formed coordination bonds at the ring port of $\beta$-cyclodextrin and prevented reactant molecules from entering the $\beta$-cyclodextrin cavity. Therefore, the glycerol conversion and GC yield decreased slightly when the content of $\mathrm{Ca}^{2+}$ in $\beta$-CD-Ca continued to mount up.

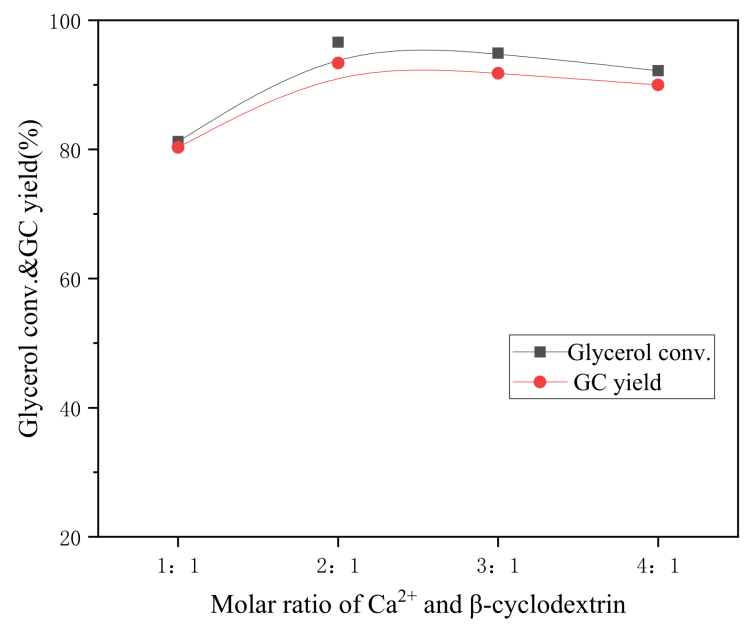

Figure 5. Effect of molar ratio of $\mathrm{Ca}^{2+}$ and $\beta-\mathrm{CD}$ on glycerol conversion and GC yield. 


\subsection{Effect of $\beta-C D-C a$ Dosage in $\beta-C D-C a / L D H$ on Transesterification}

The effect of $\beta$-CD-Ca dosage in $\beta$-CD-Ca/LDH on the catalytic performance was investigated under the conditions of 3:1 molar ratio of DMC and glycerol, $4 \mathrm{wt} . \%$ catalyst dosage, $75{ }^{\circ} \mathrm{C}$ reaction temperature and $100 \mathrm{~min}$ reaction time.

The glycerol conversion rate increased from $56.2 \%$ to $93.7 \%$ and the GC yield increased from $54.6 \%$ to $91.8 \%$ when the mass fraction of $\beta-\mathrm{CD}-\mathrm{Ca}$ in $\beta-\mathrm{CD}-\mathrm{Ca} / \mathrm{LDH}$ was risen from $10 \%$ to $20 \%$ as can be seen from Figure 6 . There was no significant change in glycerol conversion and GC yield when the content of $\beta$-CD-Ca continued to mount up. The active centers and layer spacing of hydrotalcites increased with the increase of $\beta$-CD-Ca amount, thus improving the catalytic performance on transesterification. However, the space between laminates becomes crowded with the increase of interlayer substances of hydrotalcites. Partial pores of catalyst that were blocked although active sites were ascended. Therefore, $\beta-\mathrm{CD}-\mathrm{Ca} / \mathrm{LDH}$ presented the best catalytic performance on transesterification between glycerol and DMC when the molar ratio of $\beta-C D$ and $\mathrm{Ca}^{2+}$ was $1: 2$ and the mass fraction of $\beta$-CD-Ca was $20 \%$ in $\beta$-CD-Ca/LDH.

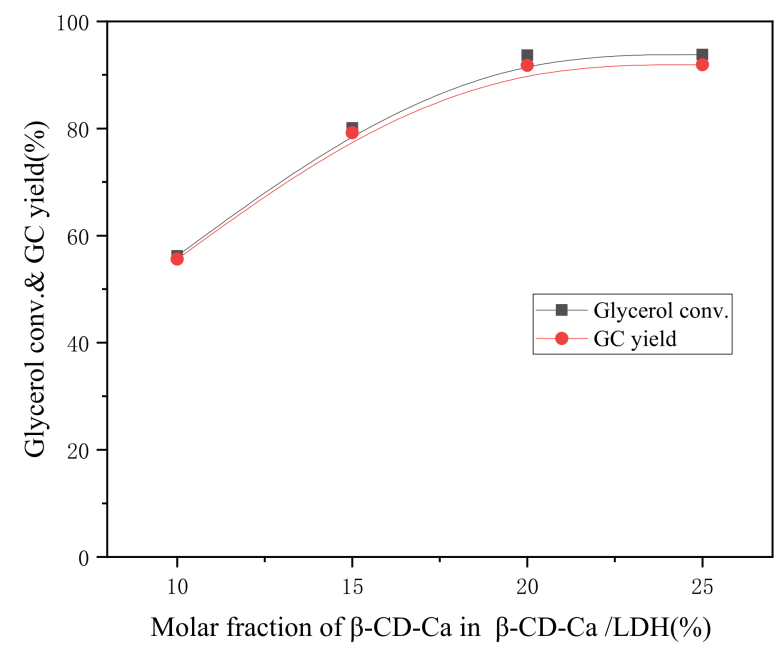

Figure 6. Effect of $\beta$-CD-Ca dosage on glycerol conversion and GC yield.

\subsection{Catalytic Performance of $\beta-C D-C a / L D H$ and $M g A l-L D H$ on Transesterification}

The catalytic performance of MgAl-LDH and $\beta-\mathrm{CD}-\mathrm{Ca} / \mathrm{LDH}$ on transesterification of dimethyl carbonate and glycerol was compared to investigate the effect of $\beta$-CD-Ca under the condition of $4 \mathrm{wt}$.\% catalyst dosage, 3:1 molar ratio of DMC to glycerol at $75{ }^{\circ} \mathrm{C}$.

The glycerol conversion increased from $42.0 \%$ to $93.7 \%$ and the GC yield increased from $41.2 \%$ to $91.8 \%$ catalyzed by $\beta-\mathrm{CD}-\mathrm{Ca} / \mathrm{LDH}$ when the reaction time rose from $60 \mathrm{~min}$ to $100 \mathrm{~min}$ in Figure $7 \mathrm{a}$. The glycerol conversion ascended from $35.0 \%$ to $49.4 \%$ and the GC yield ascended from $34.5 \%$ to $48.6 \%$ catalyzed by MgAl-LDH within the same time slot in Figure $7 \mathrm{~b}$. The glycerol conversion and GC yield only rose to about $26 \%$ at 100 min without any catalyst in Figure 7c. $\beta$-CD-Ca met the basicity requirement for transesterification reaction and the intercalation in hydrotalcites expanded the pore size of catalyst. In addition, the enrichment of organic reactants in $\beta$-cyclodextrin cavity was also beneficial to the catalytic reaction. Therefore, the catalytic performance of $\beta-\mathrm{CD}-\mathrm{Ca} / \mathrm{LDH}$ for transesterification was much better than that of MgAl-LDH. 

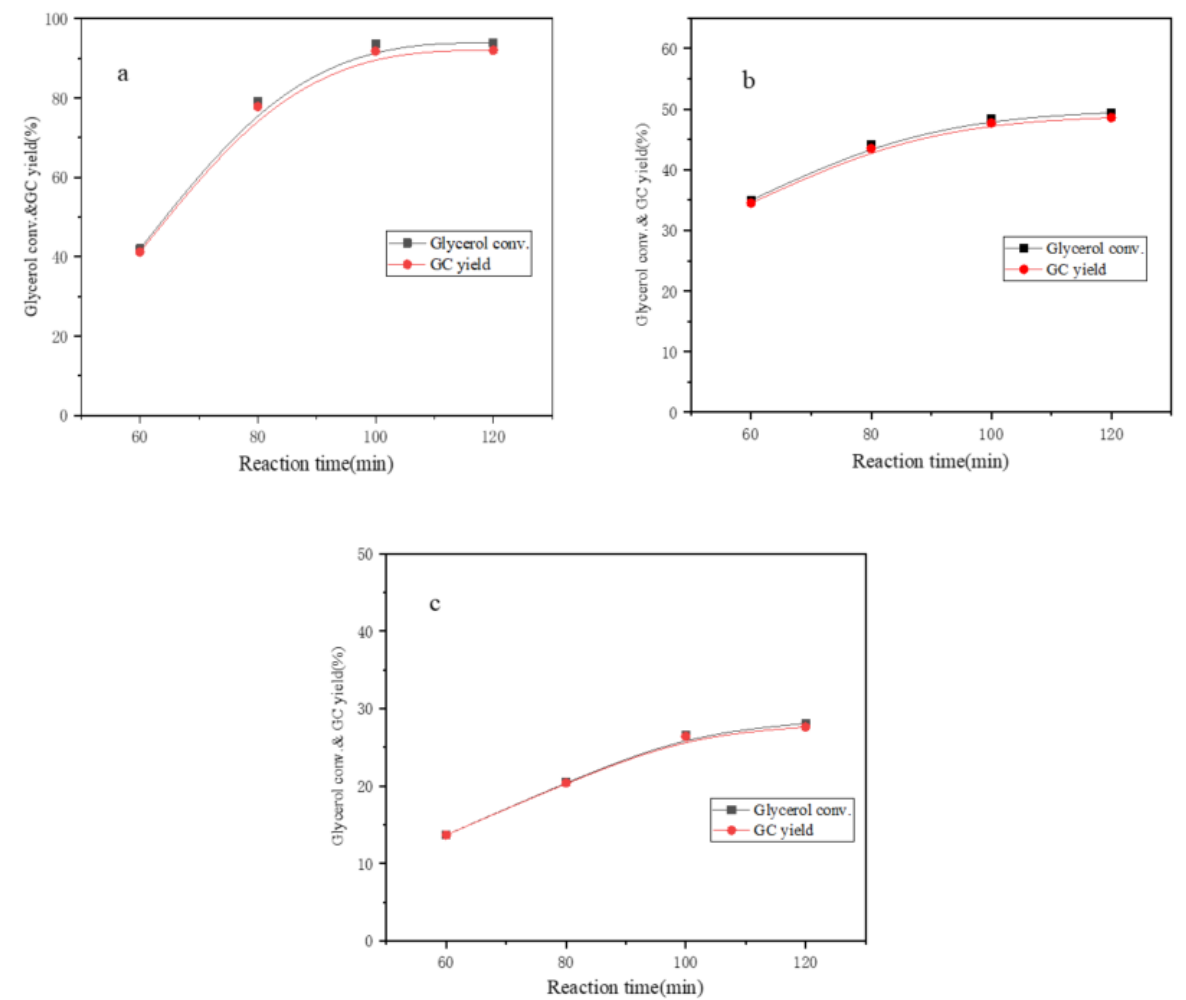

Figure 7. Glycerol conversion and GC yield catalyzed by $\beta-\mathrm{CD}-\mathrm{Ca} / \mathrm{LDH}(\mathbf{a}), \mathrm{MgAl}-\mathrm{LDH}(\mathbf{b})$ and no catalyst (c).

\subsection{Effect of Different Reaction Conditions on Transesterification}

The reaction conditions were optimized since the glycerol conversion and GC yield depended strongly on the catalyst dosage, molar ratio of reactants, reaction temperature and reaction time.

The effect of catalyst dosage on the catalytic performance was investigated as shown in Figure $8 \mathrm{a}$ when the reaction temperature was $65{ }^{\circ} \mathrm{C}$, the reaction time was $80 \mathrm{~min}$ and the molar ratio of dimethyl carbonate to glycerol was 2:1. The glycerol conversion and glycerol carbonate yield increased sharply to $80.3 \%$ and $78.9 \%$ when the amount of $\beta-\mathrm{CD}-\mathrm{Ca} / \mathrm{LDH}$ rose from $1 \mathrm{wt} . \%$ to $3 \mathrm{wt} . \%$ due to the increase of active centers. There was no obvious upward tendency in glycerol conversion and GC yield with the further increase of catalyst dosage, which was mainly because the mass transfer resistance caused by the agglomeration solid catalyst particles reduced the utilization rate of $\beta-\mathrm{CD}-\mathrm{Ca} / \mathrm{LDH}$. Therefore, $3 \mathrm{wt} . \%$ can be considered as the optimal dosage of $\beta-\mathrm{CD}-\mathrm{Ca} / \mathrm{LDH}$ in the reaction. 

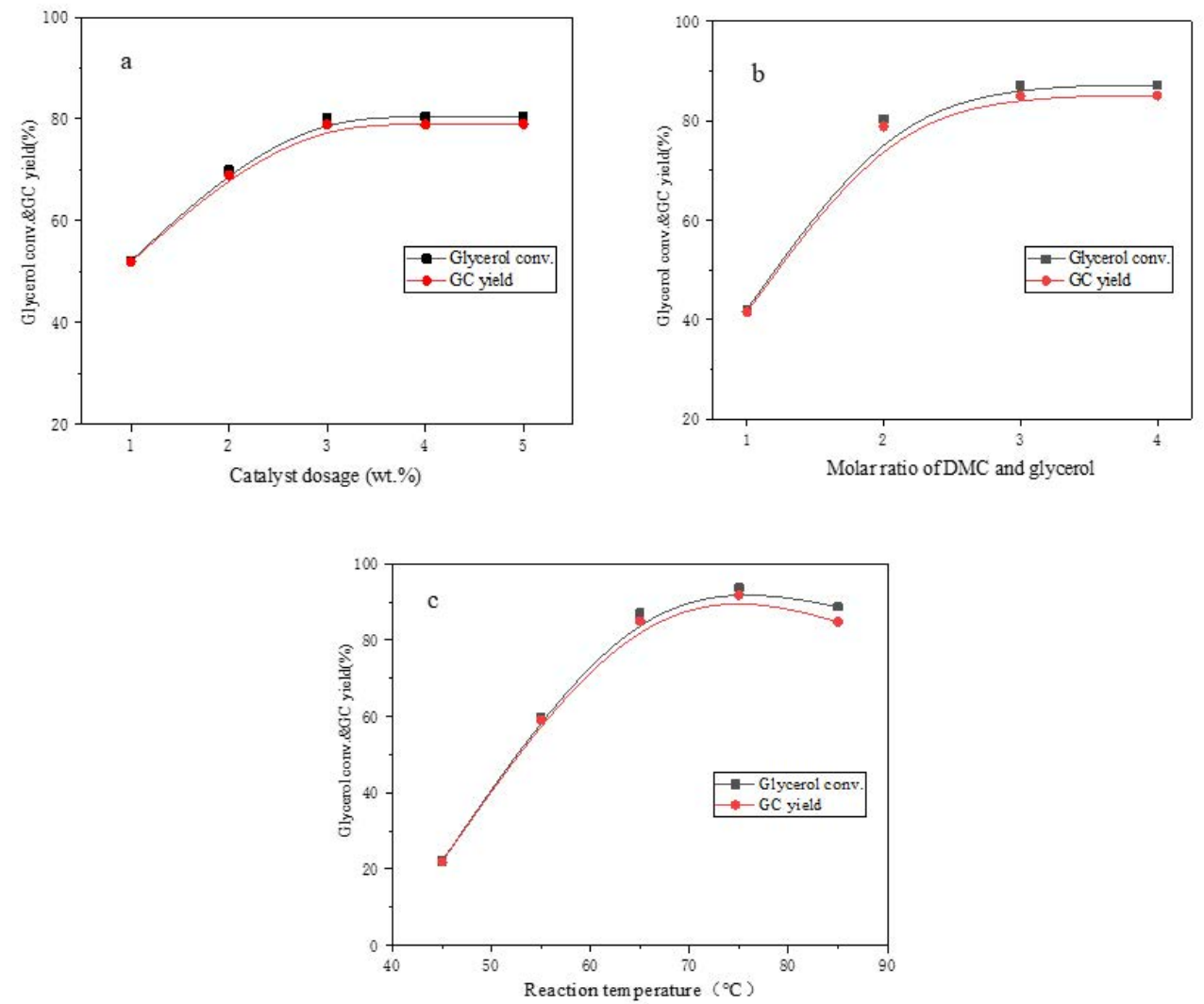

Figure 8. Effect of catalyst dosage (a), molar ratio of DMC to glycerol (b) and reaction temperature (c) on transesterification.

The effect of reactant ratio on the catalytic performance of $\beta-\mathrm{CD}-\mathrm{Ca} / \mathrm{LDH}$ was displayed in Figure 8b when the catalyst dosage was $3 \mathrm{wt} . \%$, the reaction time was $80 \mathrm{~min}$ and the reaction temperature was $65^{\circ} \mathrm{C}$. The increased reactant concentration forced the reaction equilibrium moving towards the products as the transesterification of dimethyl carbonate with glycerol was reversible. The glycerol conversion increased from $42.1 \%$ to $87.1 \%$ and GC yield increased from $41.5 \%$ to $85.0 \%$ when the molar ratio of dimethyl carbonate to glycerol ascended from 1:1 to 3:1. There was no significant change in glycerol conversion and GC yield when the proportion of dimethyl carbonate continued to mount up. Therefore, 3:1 molar ratio of dimethyl carbonate and glycerol was selected as the optimal reactant ratio for the transesterification.

The glycerol conversion and GC yield under different reaction temperature was exhibited in Figure $8 \mathrm{c}$ when the catalyst dosage was $3 \mathrm{wt} . \%$, the reaction time was $100 \mathrm{~min}$ and the molar ratio of dimethyl carbonate and glycerol was 3:1. The temperature rise of reaction system can effectively improve the collision probability of activated reaction molecules as well as increase the reaction rate. The glycerol conversion and the yield of glycerol carbonate turned out to be an ascending trend along with reaction temperature before $75^{\circ} \mathrm{C}$. However, the glycerol conversion and GC yield decreased when the temperature rose to the boiling point of dimethyl carbonate since the serious vaporization of reactant was unfavorable to the transesterification. In summary, Figures 7 and 8 indicated that $\beta-\mathrm{CD}-\mathrm{Ca} / \mathrm{LDH}$ presented best catalytic performance when the catalyst dosage was $3 \mathrm{wt} . \%$, the molar ratio of dimethyl carbonate and glycerol was 3:1, the reaction time was $100 \mathrm{~min}$ and the reaction temperature was $75^{\circ} \mathrm{C}$.

\subsection{Reuse Ability of $\beta-C D-C a / L D H$}

The catalyst reuse experiment was carried out to investigate the stability of active centers in $\beta-\mathrm{CD}-\mathrm{Ca} / \mathrm{LDH}$ for the transesterification of DMC and glycerol. The reaction conditions were consistent with the above-mentioned conditions. 
Figure 9 displayed the change of glycerol conversion during five reaction cycles. The conversion of glycerol can still reach more than $85 \%$ catalyzed by $\beta-\mathrm{CD}-\mathrm{Ca} / \mathrm{LDH}$ in the fifth cycles, which indicated $\beta-\mathrm{CD}-\mathrm{Ca}$ as active component was stable in the hydrotalcites. This was mainly because the electrostatic attraction between rich hydroxyl groups on the offside of $\beta$-cyclodextrin and metal ions in hydrotalcites enhanced the binding ability between $\beta$-CD-Ca and MgAl-LDH. Therefore, $\beta-\mathrm{CD}-\mathrm{Ca} / \mathrm{LDH}$ still presented excellent catalytic performance after five times reuse. $\mathrm{Mg}$ - $\mathrm{Al}$ hydrotalcites presented interlayer anion exchangeability as layered materials. The functional guest substances can be introduced into the layer gap and expand interlayer spacing to form pillared compounds. The formation of $\mathrm{C}-\mathrm{O}-\mathrm{Ca}-\mathrm{OH}$ after the coordination of $\beta$-cyclodextrin and calcium ions increased the negative charges of hydroxyl groups on the outside of $\beta$-cyclodextrin. The metal ions constituting the hydrotalcite laminates can be stably combined with the hydroxyl groups of $\beta$-cyclodextrin through electrostatic interaction when $\beta$-CD-Ca was intercalated into $\mathrm{MgAl}-\mathrm{LDH}$, which not only increased the layer spacing of hydrotalcites but also improved the reusability of the catalyst.

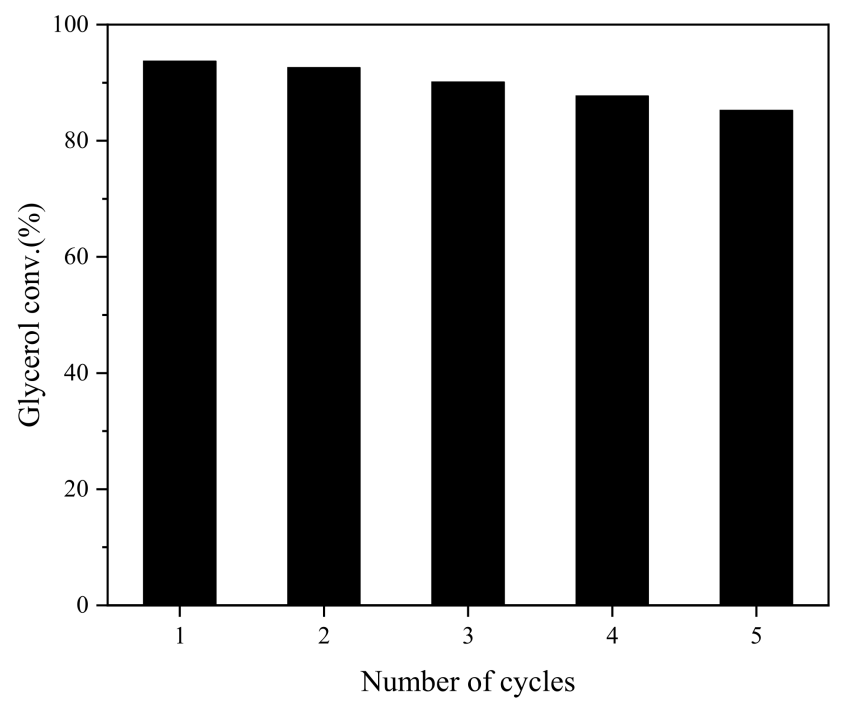

Figure 9. Reusability of $\beta-\mathrm{CD}-\mathrm{Ca} / \mathrm{LDH}$.

$\beta-\mathrm{CD}-\mathrm{Ca} / \mathrm{LDH}$ presented remarkable catalytic performance on the transesterification of dimethyl carbonate with glycerol. XRD analysis showed that $\beta$-CD-Ca increased the pore size of hydrotalcites, which enhanced mass transfer process in the reaction. The basicity determination proved that $\beta-\mathrm{CD}-\mathrm{Ca} / \mathrm{LDH}$ met the alkalinity requirement of catalysts in the transesterification due to the formation of C-O-Ca-OH observed in the FT-IR spectrum and XPS spectrum. The interaction between $\beta$-CD-Ca and MgAl hydrotalcites enabled $\beta-C D-$ $\mathrm{Ca} / \mathrm{LDH}$ to keep stable in the reaction system. Hence $\beta-\mathrm{CD}-\mathrm{Ca} / \mathrm{LDH}$ can be considered as an excellent catalyst for the synthesis of glycerol carbonate by transesterification.

\section{Experimental Methods}

\subsection{Synthesis of $\beta$-Cyclodextrin-Metal Complexes}

To form Solution A, $2.50 \mathrm{~g}(0.002 \mathrm{~mol}) \beta$-cyclodextrin and $0.80 \mathrm{~g}(0.02 \mathrm{~mol}) \mathrm{NaOH}$ were weighed and dissolved in $50 \mathrm{~mL}$ ultrapure water. To form Solution B, $0.94 \mathrm{~g}(0.004 \mathrm{~mol})$ calcium nitrate tetrahydrate was stirred and dissolved in $50 \mathrm{~mL}$ ultrapure water. Solution $\mathrm{A}$ and Solution B were mixed and stirred at room temperature $\left(25^{\circ} \mathrm{C}\right)$ for two hours. Then $400 \mathrm{~mL}$ absolute ethanol was poured into the mixture. $\beta$-CD-Ca can be obtained after filtering and drying at room temperature. The synthesis diagram was shown in Figure 10. $\beta-\mathrm{CD}-\mathrm{Zn}$ and $\beta-\mathrm{CD}-\mathrm{Ni}$ can be prepared by using zinc nitrate and nickel nitrate instead of calcium nitrate. 


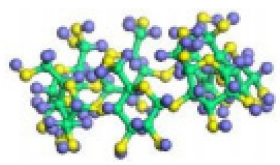

$\beta-C D$
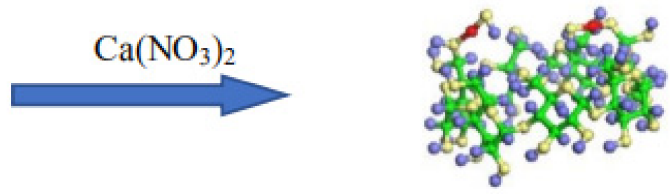

$\beta-\mathrm{CD}-\mathrm{Ca}$

Figure 10. Synthesis diagram of $\beta-C D-C a$.

\subsection{Synthesis of $\beta-C D-C a$ Intercalated $M g A l$ Hydrotalcites}

$\mathrm{Mg}\left(\mathrm{NO}_{3}\right)_{2}$ and $\mathrm{Al}\left(\mathrm{NO}_{3}\right)_{3}$ was weighed at the molar ratio of 3:1 and dissolved in $200 \mathrm{~mL}$ ultrapure water to prepare Solution $\mathrm{I}$. $\mathrm{NaOH}$ and $\mathrm{Na}_{2} \mathrm{CO}_{3}$ was weighed at the ratio of 16:1 and dissolved in ultrapure water to prepare Solution II. A certain amount of $\beta$-CD-Ca was dissolved in Solution II. Appropriate amount of ultrapure water was added into a four-neck flask and heated to $80{ }^{\circ} \mathrm{C}$. Solution I and Solution II was coprecipitated by double titration in the four-neck flask. The temperature of reaction system was kept $80^{\circ} \mathrm{C}$ and $\mathrm{pH}$ was kept between 10 and 11 with stirring. The obtained white turbid liquid was aged for $12 \mathrm{~h}$ in the thermostat water bath at $80^{\circ} \mathrm{C}$ after titration. $\beta-\mathrm{CD}-\mathrm{Ca} / \mathrm{LDH}$ can be obtained after filtering, washing by ultrapure water and drying in the vacuum oven at $80^{\circ} \mathrm{C}$ for $12 \mathrm{~h}$. The synthesis diagram of $\beta$-CD-Ca/LDH was displayed in Figure 11.

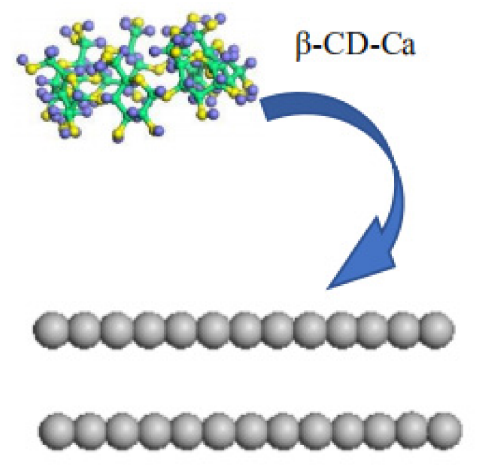

MgAl-LDH

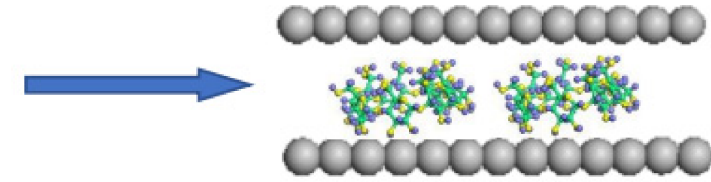

$\beta-\mathrm{CD}-\mathrm{Ca} / \mathrm{LDH}$

Figure 11. Synthesis diagram of $\beta-\mathrm{CD}-\mathrm{Ca}$ intercalated $\mathrm{Mg}-\mathrm{Al}$ hydrotalcites.

\subsection{Characterization Methods}

X-ray diffraction (XRD) patterns were recorded on RigakuD/max2550VB/PC (Rigaku International Corporation, Tokyo, Japan), using $\mathrm{CuK} \alpha$ radiation $(\lambda=0.154 \mathrm{~nm})$ at $45 \mathrm{kV}$, $100 \mathrm{~mA}$. The scanning range was from $10^{\circ}$ to $80^{\circ}(2 \theta)$ at a scan speed of $0.02^{\circ} / \mathrm{s}$ [30]. X-ray photoelectron spectra (XPS) were recorded on ESCALAB 250. The morphologies of samples were observed by scanning electron microscopy (SEM) on Sigma 300. Fourier transform infrared (FT-IR) spectra of samples were recorded on Nicolet Magna-IR 550 via KBr pellet with a wavenumber range of $200-800 \mathrm{~nm}$ [31]. $\mathrm{N}_{2}$ adsorption-desorption isotherms of the samples were recorded on Micromeritics ASAP 2460. The specific surface area was calculated by Brunauer-Emmett-Teller (BET) method. The basic strength and basic number of samples was evaluated by Hammett titration method using 4-chloroaniline $\left(\mathrm{H}_{-}=26.5\right)$, 4-nitroaniline $\left(\mathrm{H}_{-}=18.4\right)$, 2.4-dinitroaniline $\left(\mathrm{H}_{-}=15.0\right)$ and phenolphthalein $\left(\mathrm{H}_{-}=9.3\right)$ as indicators $[32,33]$.

\subsection{Transesterification Procedure}

The transesterification was conducted in a four-neck flask with the stirring device and reflux device. Glycerol and dimethyl carbonate were weighted and mixed in the reactor. Catalyst samples were added to catalyze the reaction of glycerol and dimethyl carbonate 
under $\mathrm{N}_{2}$ atmosphere when the reaction system was heated to the reaction temperature. The liquid mixture can be separated from solid catalyst by centrifugation and analyzed by Jinghe GC-7860 gas chromatograph equipped with a flame ionization detector (FID) (Agilent Technologies Inc., Santa Clara, CA, USA) and a HP-PONA capillary column $(50 \mathrm{~m} \times 0.200 \mathrm{~mm} \times 0.50 \mu \mathrm{m})$ gas chromatography [34]. Programmed temperature was used to separate the different components of the vaporized mixture in the gas chromatograph. The calculation formula of glycerol conversion and GC yield were as follows.

$$
\begin{gathered}
\text { Glycerol conversion }(\%)=\frac{\mathrm{C}_{\mathrm{Gly}_{0}}-\mathrm{C}_{\mathrm{Gly}_{\mathrm{i}}}}{\mathrm{C}_{\mathrm{Gly}_{0}}} \times 100 \% \\
\mathrm{GC} \text { yield }(\%)=\frac{\mathrm{C}_{\mathrm{GC}}}{\mathrm{C}_{\mathrm{GC}_{\mathrm{th}}}} \times 100 \%
\end{gathered}
$$

where $\mathrm{C}_{\mathrm{Gly}_{0}}$ is initial mass concentration of glycerol, $\mathrm{C}_{\mathrm{Gly}_{\mathrm{i}}}$ is final mass concentration of glycerol in the reaction system, $\mathrm{C}_{\mathrm{GC}}$ is mass concentration of glycerol carbonate at the end of reaction and $\mathrm{C}_{\mathrm{GC}}$ is theoretical concentration of glycerol carbonate at the end of reaction.

\section{Conclusions}

$\beta$-cyclodextrin derivative $\beta$-CD-Ca was introduced into the interlayer of MgAl hydrotalcites by intercalation method to prepare $\beta-\mathrm{CD}-\mathrm{Ca} / \mathrm{LDH}$ catalyst for the preparation of glycerol carbonate by transesterification of dimethyl carbonate with glycerol. The intercalation of $\beta-C D-C a$ not only increased the alkalinity of hydrotalcites but also expanded the interlayer spacing of hydrotalcites, thus increasing the pore size of catalyst and reducing the mass transfer resistance in the transesterification. The enrichment of organic reactants in the hydrophobic cavity of $\beta$-cyclodextrin also raised the collision probability of activated molecules. The glycerol conversion and GC yield was $93.7 \%$ and $91.8 \%$ respectively catalyzed by $\beta-\mathrm{CD}-\mathrm{Ca} / \mathrm{LDH}$ when the molar ratio of $\mathrm{DMC}$ and glycerol was 3:1, the catalyst dosage was $4 \mathrm{wt} . \%$, the reaction temperature was $75^{\circ} \mathrm{C}$ and the reaction time was $100 \mathrm{~min}$. Moreover, $\beta-\mathrm{CD}-\mathrm{Ca} / \mathrm{LDH}$ presented significant reusability. The glycerol conversion can still reach more than $85 \%$ in the fifth reaction cycle. Therefore, $\beta-\mathrm{CD}-\mathrm{Ca} / \mathrm{LDH}$ can be considered as solid base catalyst with potential application value in industry.

Author Contributions: Conceptualization, G.L. and J.Y.; methodology, G.L.; software, J.Y.; validation, G.L., J.Y. and X.X.; resources; data curation, G.L.; writing-original draft preparation, G.L.; writing-review and editing, X.X. and J.Y.; visualization, X.X.; supervision, X.X. All authors have read and agreed to the published version of the manuscript.

Funding: This research received no external funding.

Institutional Review Board Statement: Not applicable.

Informed Consent Statement: Not applicable.

Conflicts of Interest: The authors declare no conflict of interest.

\section{References}

1. Li, W.; Wang, X.; Jiang, T. One-pot synthesis of b-cyclodextrin modified Aunanoclusters with near-infrared emission. Chem. Commun. 2020, 56, 5580-5583. [CrossRef] [PubMed]

2. Yao, X.; Zheng, H.; Zhang, Y. Engineering Thiol-Ene Click Chemistry for the Fabrication of Novel Structurally Well-Defined Multifunctional Cyclodextrin Separation Materials for Enhanced Enantioseparation. Anal. Chem. 2016, 88, 4955-4964. [CrossRef] [PubMed]

3. Chen, Y.; Yu, B.; Cui, Y. Core-Shell Structured Cyclodextrin Metal-Organic Frameworks with Hierarchical Dye Encapsulation for Tunable Light Emission. Chem. Mater. 2019, 31, 1289-1295. [CrossRef]

4. Zhao, Y.; Huang, Y.; Zhu, H. Three-in-One: Sensing, Self-Assembly, and Cascade Catalysis of Cyclodextrin Modified Gold Nanoparticles. J. Am. Chem. Soc. 2016, 138, 16645-16654. [CrossRef]

5. Li, N.; Qi, L.; Qiao, J. Ratiometric Fluorescent Pattern for Sensing Proteins Using Aqueous Polymer-Pyrene/ $\gamma$-Cyclodextrin Inclusion Complexes. Anal. Chem. 2016, 88, 1821-1826. [CrossRef] 
6. Ji, J.; Wu, W.; Liang, W. An Ultimate Stereocontrol in Supramolecular Photochirogenesis: Photocyclodimerization of 2Anthracenecarboxylate Mediated by Sulfur-Linked $\beta$-Cyclodextrin Dimers. J. Am. Chem. Soc. 2019, 141, 9225-9238. [CrossRef]

7. Nkinahamira, F.; Alsbaiee, A.; Zeng, Q. Selective and fast recovery of rare earth elements from industrial wastewater by porous b-cyclodextrin and magnetic b-cyclodextrin polymers. Water Res. 2020, 181, 115857. [CrossRef]

8. Shakya, S.; He, Y.; Ren, X. Ultrafine Silver Nanoparticles Embedded in Cyclodextrin Metal-Organic Frameworks with GRGDS Functionalization to Promote Antibacterial and Wound Healing Application. Small 2019, 15, 1901065. [CrossRef]

9. Guo, J.; Li, D.; Tao, H. Cyclodextrin-Derived Intrinsically Bioactive Nanoparticles for Treatment of Acute and Chronic Inflammatory Diseases. Adv. Mater. 2019, 31, 1904607. [CrossRef]

10. Zhou, N.; Peng, L.; Salgado, S. Synthesis of Air-Stable Cyclopentadienyl Fe $(\mathrm{CO})_{2}(\mathrm{Fp})$ Polymers by a Host-Guest Interaction of Cyclodextrin with Air-Sensitive Fp Pendant Groups. Angew. Chem. Int. Ed. 2017, 56, 6246-6250. [CrossRef]

11. Chen, X.; Liu, L.; Huo, M. Direct Synthesis of Polymer Nanotubes by Aqueous Dispersion Polymerization of a Cyclodextrin/Styrene Complex. Angew. Chem. Int. Ed. 2017, 56, 16541-16545. [CrossRef]

12. Prochowicz, D.; Kornowicz, A.; Lewinsk, J. Interactions of Native Cyclodextrins with Metal Ions and Inorganic Nanoparticles: Fertile Landscape for Chemistry and Materials Science. Chem. Rev. 2017, 117, 13461-13501. [CrossRef]

13. Tran, D.N.; Legrand, F.X.; Menuel, S.; Bricout, H.; Tilloy, S.; Monflier, E. Cyclodextrin-phosphane possessing a guest-tunable conformation for aqueous rhodium-catalyzed hydroformylation. Chem. Commun. 2011, 48, 753-755. [CrossRef]

14. Zhao, Y.; Jia, X.; Chen, G. Ultrafine NiO Nanosheets Stabilized by TiO2from Monolayer NiTi-LDH Precursors: An Active Water Oxidation Electrocatalyst. J. Am. Chem. Soc. 2016, 138, 6517-6524. [CrossRef]

15. Lin, Y.; Fang, Q.; Chen, B. Metal composition of layered double hydroxides (LDHs) regulating $\mathrm{ClO}(-) 4$ adsorption to calcined LDHs via the memory effect and hydrogen bonding. J. Environ. Sci. 2014, 26, 493-501. [CrossRef]

16. Shivaji LBhanawase Ganapati, D. Yadav. Novel Silica-Encapsulated Cu-Al Hydrotalcite Catalyst: Oxidative Decarboxylation of Vanillyl Mandelic Acid to Vanillin in Water at Atmospheric Pressure. Ind. Eng. Chem. Res. 2017, 56, 12899-12908.

17. Kondawar, S.; Rode, C. Solvent-Free Glycerol Transesterification with Propylene Carbonate to Glycerol Carbonate over a Solid Base Catalyst. Energy Fuels 2017, 31, 4361-4371. [CrossRef]

18. Takagaki, A.; Iwatani, K.; Nishimura, S.; Ebitani, K. Synthesis of glycerol carbonate from glycerol and dialkyl carbonates using hydrotalcite as a reusable heterogeneous base catalyst. Green Chem. 2010, 12, 578-581. [CrossRef]

19. Szabados, M.; Ádám, A.A.; Traj, P.; Muráth, S.; Baán, K.; Bélteky, P.; Kónya, Z.; Kukovecz, Á.; Sipos, P.; Pálinkó, I. Mechanochemical and wet chemical syntheses of CaIn-layered double hydroxide and its performance in a transesterification reaction compared to those of other Ca2M(III) hydrocalumites (M: Al, Sc, V, Cr, Fe, Ga) and Mg(II)-, Ni(II)-, Co(II)- or Zn(II)-based hydrotalcites. J. Catal. 2020, 391, 282-297. [CrossRef]

20. Zheng, L.; Xia, S.; Hou, Z.; Zhang, M.; Hou, Z. Transesterification of glycerol with dimethyl carbonate over Mg-Al hydrotalcites. Chin. J. Catal. 2015, 36, 1759-1765. [CrossRef]

21. Granados-Reyes, J.; Salagre, P.; Cesteros, Y. CaAl-layered double hydroxides as active catalysts for the transesterification of glycerol to glycerol carbonate. Appl. Clay Sci. 2016, 132-133, 216-222. [CrossRef]

22. bin Hussein, M.Z.; Zainal, Z.; Yahaya, A.H.; Foo DW, V. Controlled release of a plant growth regulator, $\alpha$-naphthaleneacetate from the lamella of Zn-Al-layered double hydroxide nanocomposite. J. Control. Release 2002, 82, 417-427. [CrossRef]

23. Zhao, Y.; Chen, G.; Bian, T. Defect-Rich Ultrathin ZnAl-Layered Double Hydroxide Nanosheets for Efficient Photoreduction of CO2 to CO with Water. Adv. Mater. 2015, 27, 7824-7831. [CrossRef]

24. Yang, Y.; Dang, L.; Shearer, M.J. Highly Active Trimetallic NiFeCr Layered Double Hydroxide Electrocatalysts for Oxygen Evolution Reaction. Adv. Energy Mater. 2018, 8, 1703189. [CrossRef]

25. An, Z.; Ma, H.; Han, H. Insights into the Multiple Synergies of Supports in the Selective Oxidation of Glycerol to Dihydroxyacetone: Layered Double Hydroxide Supported Au. ACS Catal. 2020, 10, 12437-12453. [CrossRef]

26. Lu, Z.; Qian, L.; Tian, Y. Ternary NiFeMn layered double hydroxides ashighly-efficient oxygen evolution catalysts. Chem. Commun. 2016, 52, 908-911. [CrossRef]

27. Zhao, Y.; Zhao, Y.; Zheng, L. Layered-Double-Hydroxide Nanosheets as Efficient Visible-Light-Driven Photocatalysts for Dinitrogen Fixation. Adv. Mater. 2017, 29, 1703828. [CrossRef]

28. Wang, J.; Wei, M.; Rao, G.; Evans, D.G.; Duan, X. Structure and thermal decompositioin of sulfated $\beta$-cyclodextrin intercalated in a layered double hydroxide. J. Solid Sate Chem. 2004, 177, 366-371. [CrossRef]

29. Mohanambe, L.; Vasudevan, S. Orientational dynamics of anthracene in a cyclodextrin functionalized layered solid. J. Phys. Chem. B 2005, 109, 11865-11869. [CrossRef]

30. Zanjani, N.G.; Kamran-Pirzaman, A.; Khalajzadeh, M. Synthesis of modified layered double hydroxide of MgAl catalyst with Ba and Li for the biodiesel production. Clean Technol. Environ. Policy 2020, 22, 1173-1185. [CrossRef]

31. Liu, G.; Yang, J.; Xu, X. Synthesis of Hydrotalcites from Waste Steel Slag with [Bmim]OH Intercalated for the Transesterification of Glycerol Carbonate. Molecules 2020, 25, 4355. [CrossRef] [PubMed]

32. Bing, W.; Wang, H.; Lei, Z.; Rao, D.; Yang, Y.; Zheng, L.; Wang, B.; Wang, Y.; Wei, M. CaMnAl-hydrotalcite solid basic catalyst toward aldol condensation reaction with a comparable level to liquid alkali catalysts. Green Chem. 2018, 20, 3071-3080. [CrossRef]

33. Wang, Y.; Huang, W.Y.; Chun, Y.; Xia, J.R.; Zhu, J.H. Dispersion of potassium nitrate and the resulting strong basicity on zirconia. Chem. Mater. 2001, 13, 670-677. [CrossRef] 
34. Xie, W.; Li, H. Alumina-supported potassium iodide as heterogeneous catalyst for biodiesel production from soybean oil. J. Mol. Catal. A Chem. 2006, 255, 1-9. [CrossRef] 